\title{
Platelet-derived Growth Factor Enhances In Vitro Erythropoiesis Via Stimulation of Mesenchymal Cells
}

\author{
Francis Delwiche, Elaine Raines, Jerry Powell, Russell Ross, and John Adamson \\ Division of Hematology, Department of Medicine, and the Department of Pathology, University of Washington School of Medicine, \\ Seattle, Washington 98195
}

\begin{abstract}
The growth of erythroid colonies (from erythroid colonyforming cells) and erythroid bursts (from burst-forming cells [BFU-E]) is enhanced in the presence of serum as compared with plasma. A significant proportion of the enhanced growth is due to the platelet release product, platelet-derived growth factor (PDGF). Colony growth in cultures of whole marrow cells in platelet-poor plasma-derived serum (PDS) and erythropoietin was enhanced in a dose-dependent fashion by increasing concentrations of purified human PDGF with optimal enhancement at $12.5 \mathrm{ng} / \mathrm{ml}$. However, no effect of plateletrelease products or PDGF was observed on nonadherent human marrow cells or peripheral blood BFU-E, suggesting that an accessory cell population was required for the effect of PDGF on hematopoietic progenitors. In a two-layer culture system, pure populations of fibroblasts or smooth muscle cells, known to be present in the marrow microenvironment, restored the response of nonadherent marrow cells in the overlayer to PDGF and also conferred responsiveness to peripheral blood BFU-E. Endothelial cells in the two-layer culture system and macrophages, in contrast, lacked the ability to restore the enhancing effect of PDGF. Because other platelet-release mitogenic products are also found in serum, a monospecific anti-PDGF IgG preparation was added to cultures grown in platelet rich plasma-derived serum. Only partial reduction in colony and burst growth was seen, suggesting that other platelet-release products were acting in this system. These results demonstrate that PDGF enhancement of human hematopoietic progenitor cell growth requires mesenchymal cells, and provide an example and mechanism by which growth factors may influence hematopoietic progenitors via cells of the marrow microenvironment.
\end{abstract}

\section{Introduction}

Recently it has been reported that platelet-derived growth factor (PDGF) ${ }^{1}$ enhances erythropoiesis when added to cultures of human marrow cells (1). Since no specific PDGF receptor

Dr. Delwiche was the recipient of a Scientific Medical Research Foundation Award from the Fonds de la Recherche Scientifique Medicale, Brussels, Belgium.

Received for publication 17 April 1984 and in revised form 6 February 1985.

1. Abbreviations used in this paper: BFU-E, burst-forming cells; CFUE, erythroid colony-forming cells; Ep, erythropoietin; FCS, fetal calf serum; PDGF, platelet-derived growth factor, PDS, platelet-poor plasmaderived serum; PRS, platelet-rich plasma-derived serum.

J. Clin. Invest.

(C) The American Society for Clinical Investigation, Inc.

0021-9738/85/07/0137/06 \$1.00

Volume 76, July 1985, 137-142 has been demonstrated on lymphoid cells (2), and since PDGF has been shown to be specific for connective tissue cells $(2,3)$, we investigated the mechanisms underlying the enhancing properties of PDGF and other platelet-release products on human erythroid progenitor growth.

Our studies confirm that human erythroid colony and erythroid burst growth in vitro is enhanced both by products of platelet release and purified PDGF. However, our data suggest that PDGF is not the only platelet-derived factor capable of stimulating in vitro erythropoiesis, and that the enhancing effect of PDGF, itself, is dependent upon a population of adherent cells in the marrow.

\section{Methods}

Preparation of platelet-poor plasma-derived serum (PDS) and platelet-rich plasma-derived serum (PRS)

Blood was drawn into an ice-cold plastic syringe containing $7.6 \%$ sodium citrate to give a final concentration of $0.38 \%$ (vol $/ \mathrm{vol})$. The sample was mixed and centrifuged at $200 \mathrm{~g}$ for $15 \mathrm{~min}$ at $4^{\circ} \mathrm{C}$ to remove erythrocytes and nucleated cells. The supernatant (platelet-rich plasma) was removed and divided into two equal portions. One portion, to be used to make platelet-rich serum, was left at room temperature. The other portion was recentrifuged at $11,000 \mathrm{~g}$ for $1 \mathrm{~h}$ at $4^{\circ} \mathrm{C}$ and the supernatant, the platelet-poor plasma, was removed. To promote clotting, $\mathrm{CaCl}_{2}$ was added to each plasma at a final concentration of $12.5 \mathrm{mM}$, and the samples were left at room temperature for $8 \mathrm{~h}$. Fibrin clot was separated by centrifugation at $1,500 \mathrm{~g}$ for $15 \mathrm{~min}$. PRS and PDS were inactivated at $56^{\circ} \mathrm{C}$ for 45 min and sterilized by passage through a $0.45-\mu \mathrm{m}$ filter (Millipore Corp., Bedford, MA). $1-\mathrm{ml}$ aliquots of each serum were stored at $-20^{\circ} \mathrm{C}$ until used.

\section{Isolation of cell populations}

Whole marrow cells. Human blood and marrow cells were obtained from normal volunteers with informed consent and approval of the University of Washington School of Medicine Human Subjects Committee.

Marrow cells were aspirated from the posterior iliac crests of normal volunteers and diluted tenfold with alpha medium (Flow Laboratories, Rockville, MD). Mononuclear cells were separated over lymphocyte separation medium $(1.077 \mathrm{~g} / \mathrm{ml}$; Bionetics Laboratory Products, Kensington, MD). Interface cells were harvested and washed three times in alpha medium before being plated at the appropriate concentration. Marrow adherent cells were removed by a modification of the technique described by Messner et al. (4). Marrow mononuclear cells were incubated in alpha medium containing $10 \%$ PDS in polystyrene culture flasks (Corning Glass Works, Corning, NY) twice for $2 \mathrm{~h}$ each at $37^{\circ} \mathrm{C}$. Nonadherent cells were removed by gentle pipetting, centrifuged at $200 \mathrm{~g}$ for $10 \mathrm{~min}$, and plated at the appropriate concentration.

Peripheral blood mononuclear cells. Blood from normal donors was collected into lightly heparinized syringes and diluted in an equal volume of alpha medium. Mononuclear cells were separated by centrifugation over lymphocyte separation medium, washed three times in alpha medium, and then plated. 
Other cell types used. Normal human dermal fibroblasts were kindly provided by Dr. Thomas Norwood, University of Washington, Seattle, WA. Human smooth muscle cells were obtained as described previously (5) from the media of the superficial femoral artery or abdominal aorta from adult males undergoing superficial femoral artery bypass surgery. Human umbilical cord endothelial cells were kindly provided by Dr. John Harlan, University of Washington, Seattle, and were isolated using procedures described by Wall et al. (6).

\section{Erythroid colony assay}

Erythroid colony- and burst-forming cells (CFU-E and BFU-E, respectively), were cultured in methylcellulose using a modification of the technique originally described by Iscove et al. (7). $1 \mathrm{ml}$ of the final culture medium contained 1\% methylcellulose (MCV Manufacturing Chemicals, Inc., Norwood, $\mathrm{OH}$ ), 30\% fetal calf serum (FCS; Reheis Chemical Co., Phoenix, AZ) or appropriate concentrations of PDS or PRS, 1\% bovine serum albumin (BSA; Sigma Chemical Co., St. Louis, $\mathrm{MO}), 80 \mu \mathrm{g}$ streptomycin, and $80 \mathrm{U}$ penicillin. Thiol-containing compounds were deleted from the cultures. Whole marrow or nonadherent marrow cells were plated at a concentration of $10^{5} / \mathrm{ml}$ in the presence of $1.5 \mathrm{U} / \mathrm{ml}$ of human urinary erythropoietin $(\mathrm{Ep} ; \simeq 500$ $\mathrm{U} / \mathrm{mg}$ protein). ${ }^{2}$ After $7 \mathrm{~d}$ of incubation at $37^{\circ} \mathrm{C}$ in a high humidity, $4.5 \% \mathrm{CO}_{2}-95.5 \%$ air tissue culture incubator, the plates were examined with an inverted microscope. Aggregates of eight or more hemoglobinized cells were scored as CFU-E-derived colonies. After $13 \mathrm{~d}$ of incubation, the same plates were examined and aggregates comprised of 50 or more hemoglobinized cells or three or more clusters of hemoglobinized cells were scored as BFU-E-derived colonies. When all experiments were analyzed, the cloning efficiencies for CFU-E- and BFU-E-derived marrow colonies were $133 \pm 13$ (SEM) and $53 \pm 5$ per $10^{5}$ cells plated, respectively, and were optimal in $30 \%$ FCS.

Peripheral blood mononuclear cells were plated at a concentration of $2.5 \times 10^{5} / \mathrm{ml}$ and cultured in the same conditions described above. BFU-E-derived colonies were scored after $11 \mathrm{~d}$ of incubation. To study the interactions between PDGF and other cell types, a two-layer culture technique was used in which $10^{3}$ fibroblasts, smooth muscle cells, or endothelial cells were allowed to adhere for $2 \mathrm{~h}$ to the bottom of the culture dish, the medium decanted, and then $1.0 \mathrm{ml}$ of media in $0.5 \%$ agar was added. The overlayer contained $10^{5}$ nonadherent marrow cells in $1.0 \mathrm{ml}$ of the same methylcellulose mixture as described above.

\section{$P D G F$ and anti-PDGF antibody}

Highly-purified PDGF was prepared as described by Raines and Ross (8) and radioiodinated using the iodine monochloride method described by Bowen-Pope and Ross (3). Protein concentrations were determined by the method of Lowry et al. (9) using BSA as a standard. The purity of the PDGF was determined to be $93 \%$ by scans of silver stained gels (8), and by determination of the fraction of ${ }^{125}$ I-PDGF capable of specific, high-affinity binding to cultured cells (3). The PDGF preparation was dissolved in $1 \mathrm{mM}$ acetic acid and diluted in alpha medium supplemented with BSA (final BSA concentration of $2 \mathrm{mg} / \mathrm{ml}$ ).

Monospecific antiserum to PDGF was prepared in a goat using purified antigen (8). The anti-PDGF removes PDGF activity from PRS as determined by PDGF competitive activity in the radioreceptor assay, and does not recognize platelet factor $4, \beta$-thromboglobulin, or thrombospondin (three other alpha granule constituents) by radioimmunoprecipitation, nor does it alter the mitogenic activity of three other known growth factors-insulin, epidermal growth factor, or

2. The Ep used in these experiments was partially purified in our laboratory from urine pooled from a patient with pure red cell aplasia. The purification scheme is a modification of that reported by Iscove et al. (7), which includes concanavalin A chromatography to reduce colony-stimulating and erythroid burst-promoting activities. This Ep preparation lacked inhibition of erythroid colony or burst growth at concentrations of up to 5.0 and $10.0 \mathrm{U} / \mathrm{ml}$ culture, respectively. fibroblast growth factor. The IgG fraction was purified by $\mathrm{Na}_{2} \mathrm{SO}_{4}$ precipitation and chromatography on DEAE-Sephacel. The IgG fraction from a nonimmunized goat was prepared by the same procedure.

\section{Determination of PDGF levels}

PDGF levels were determined in PDS, PRS, and FCS by a modification of the radioreceptor assay described by Bowen-Pope and Ross (3). Subconfluent cultures of human foreskin fibroblasts were plated in $1 \%$ human PDS in $2 \mathrm{~cm}^{2}$ Costar (Costar, Cambridge, MA) 24-well culture dishes. The media were aspirated, the cells washed once, and the media replaced with $1.0 \mathrm{ml} /$ well of ice-cold binding medium (Hepesbuffered Ham's medium F12 [Gibco Laboratories, Grand Island, NY] adjusted to $\mathrm{pH} 7.4$ ) containing $2 \%$ (vol/vol) calf CMS-1 (calf serum incubated with CM-Sephadex to remove PDGF) (10) and the sera to be tested, or standard concentrations of pure unlabeled PDGF. The cultures were incubated at $4^{\circ} \mathrm{C}$ on an oscillating table for $3 \mathrm{~h}$. The test solutions were then removed by aspiration, the wells rinsed once with phosphate-buffered saline (PBS) containing $0.1 \%$ BSA, and then allowed to incubate for an additional hour at $4^{\circ} \mathrm{C}$ with $1.0 \mathrm{ml} /$ well of binding medium containing $0.5 \mathrm{ng}{ }^{135} \mathrm{I}-\mathrm{PDGF} / \mathrm{ml}$. The ${ }^{125} \mathrm{I}$-PDGF bound was determined as previously described (3), and the PDGF content of an unknown sample determined from a standard curve of purified PDGF.

\section{Data analysis}

To compare results between experiments, colony numbers were normalized to control cultures. The data presented are based on three or more separate experiments performed in triplicate ( 12 cultures/point). The $P$ values for statistical significance were obtained from the $F$ test for treatment effect of a repeated measures design.

\section{Results}

Comparison of erythroid colony growth and PDGF levels in $P D S$ and PRS. To define the requirement for plasma components to optimize erythroid colony growth in the absence of platelet-release factors, plating efficiencies were determined in the presence of increasing concentrations of PDS. Under all conditions studied, erythroid colonies were observed only when Ep was added to the cultures, and optimal growth of erythroid colonies was observed in the presence of 30\% FCS. The greatest numbers of erythroid colonies in plasma were observed with 5\% PDS (Fig. 1). Under these conditions, the cloning efficiencies for CFU-E- and BFU-E-derived colonies were $67.0 \pm 7.0$ (SEM) and $16.0 \pm 2.0$ per $10^{5}$ marrow cells plated, respectively.

Fig. 2 demonstrates that 5\% PRS, which contains plateletrelease factors, more effectively supported erythroid colony growth from marrow than did the optimal plasma concentration, 5\% PDS. The enhancing effects seen for PRS over PDS on CFU-E and BFU-E growth were similar $(+50$ and $+47 \%$, respectively). However, when compared with the in vitro conditions of growth in $30 \%$ FCS, the recovery for CFU-E was higher than for BFU-E (84\% of optimal numbers vs. $57 \%$ ). Contrary to the results obtained with marrow cells, the presence of platelet-release products in PRS did not enhance the growth of peripheral blood BFU-E compared with PDS (data not shown). The levels of one platelet component, PDGF, were determined by radioreceptor assay (3) for each serum used. FCS contained $1.25 \mathrm{ng} / \mathrm{ml}(0.36 \mathrm{ng} /$ culture in $30 \%$ FCS $)$, PRS contained $14.0 \mathrm{ng} / \mathrm{ml}(0.7 \mathrm{ng} /$ culture in 5\% PRS), and PDS contained no detectable PDGF $(<0.04 \mathrm{ng} / \mathrm{ml})$.

Effect of a PDGF antibody on the enhancing properties of $P R S$. To determine if the enhancing effects of PRS were due solely to PDGF, the PDS and PRS were incubated for $1 \mathrm{~h}$ at $37^{\circ} \mathrm{C}$ with a goat anti-human PDGF IgG preparation. The 


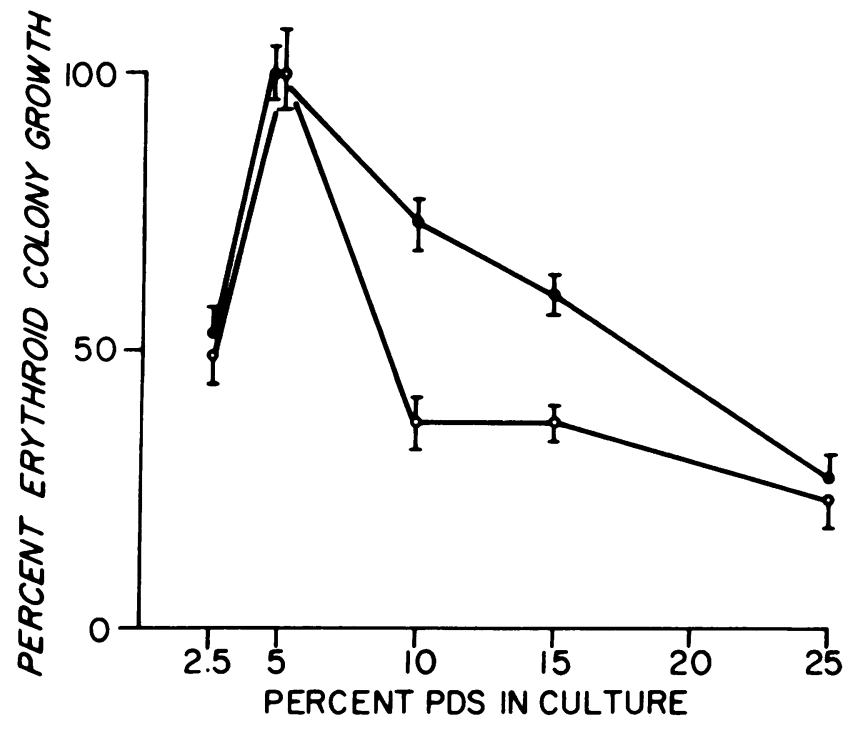

Figure 1. The influence of increasing concentrations of PDS on erythroid burst (๑) and erythroid colony (0) growth. The erythroid colony assay was performed as described in Methods, and all cultures contained $1.5 \mathrm{U} \mathrm{Ep} / \mathrm{ml}$. Optimal colony numbers were consistently seen at 5\% PDS concentration (100\% erythroid colony growth). Under these conditions, the mean ( \pm SEM) cloning efficiencies for CFUE- and BFU-E-derived colonies were $67( \pm 7.0)$ and $16( \pm 2.0)$ per $10^{5}$ marrow cells plated, respectively. The graph represents the mean \pm SEM for three separate experiments carried out in triplicate.

monospecific anti-PDGF IgG, at a concentration of $20 \mu \mathrm{g} / \mathrm{ml}$, completely inhibited $1 \mathrm{ng} / \mathrm{ml}$ purified PDGF or an equivalent amount of PDGF in PRS, as determined by assay of mitogenic activity or ability to compete with ${ }^{125} \mathrm{I}-\mathrm{PDGF}$ in the radioreceptor assay (data not shown).

The concentration of IgG used in experiments, shown in Fig. 2, was based on the serum level of PDGF determined by radioreceptor assay, and either a three- or sixfold excess was used (i.e., for a PDGF level of $1 \mathrm{ng} / \mathrm{ml}$, either 60 or $120 \mu \mathrm{g} /$ $\mathrm{ml}$ of anti-PDGF IgG was used). In individual experiments,

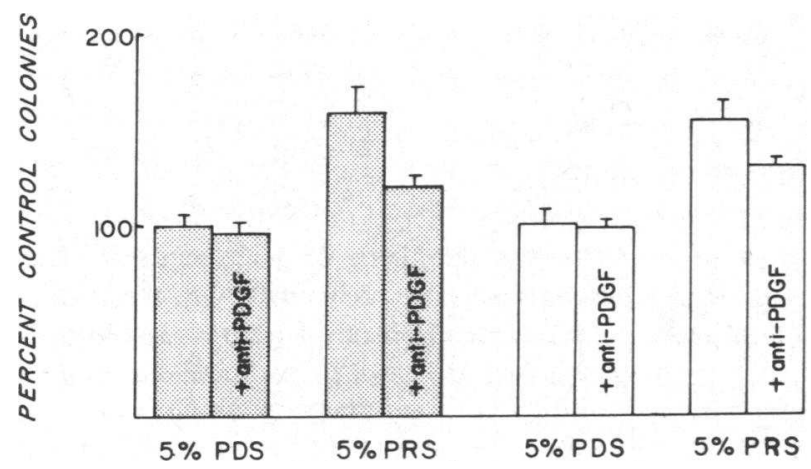

Figure 2. Erythroid colony and burst growth were compared in 5\% PRS and 5\% PDS in the presence and absence of anti-PDGF IgG. The PRS and PDS were incubated for $1 \mathrm{~h}$ at $37^{\circ} \mathrm{C}$ with or without a sixfold excess of anti-PDGF IgG (calculated from antibody neutralization data and PDGF levels of PRS; see text) before addition to the cultures. Data are expressed as the mean $( \pm$ SEM) percentage of erythroid colonies (stippled bars) and bursts (open bars) as compared with control cultures in 5\% PDS (100\%). Results are based on six separate studies conducted in triplicate. the effects of a three- or sixfold excess of the antibody gave similar results. Neutralizing concentrations of anti-PDGF antibody (sixfold excess) had no effect on CFU-E or BFU-E growth in PDS, while the same concentration inhibited colony growth in PRS by 66 and 37\% for CFU-E and BFU-E, respectively (Fig. 2). Equivalent concentrations of nonimmune goat IgG had no effect on CFU-E or BFU-E growth in PRS or PDS (data not shown).

Effect of pure PDGF on progenitor cell growth. When increasing concentrations of pure PDGF were added to cultures containing 5\% PDS, a dose-dependent enhancement of CFU$\mathrm{E}$ and BFU-E growth was observed (Fig. 3). In these experimental conditions, $12.5 \mathrm{ng}$ PDGF/ml gave the maximal stimulatory effect $(+60$ and $+48 \%$ for CFU-E and BFU-E growth, respectively). As compared with the usual conditions of growth in $30 \% \mathrm{FCS}$, the recovery for BFU-E was lower (71\%) than for CFU-E (93\%), similar to the recoveries observed in PRS. The same concentration of PDGF failed to stimulate the growth of peripheral blood BFU-E (Fig. 4).

Cellular requirements for enhancement of erythroid colony growth by PDGF. Optimal concentrations of pure PDGF were then used to investigate the role of adherent cells in the enhancing effect. As shown in Fig. 4, PDGF failed to stimulate marrow CFU-E or BFU-E growth in the absence of adherent cells. To further define the target cell(s) involved in the response to PDGF, target and potential effector cells were cultured in two layers. Nonadherent marrow cells $\left(10^{5}\right)$, shown to be unresponsive to PDGF (Fig. 4), were grown in $1 \%$ methylcellulose in the overlayer. The underlayer $(0.5 \%$ agar $)$ contained a pure population of $10^{3}$ cells known to be present

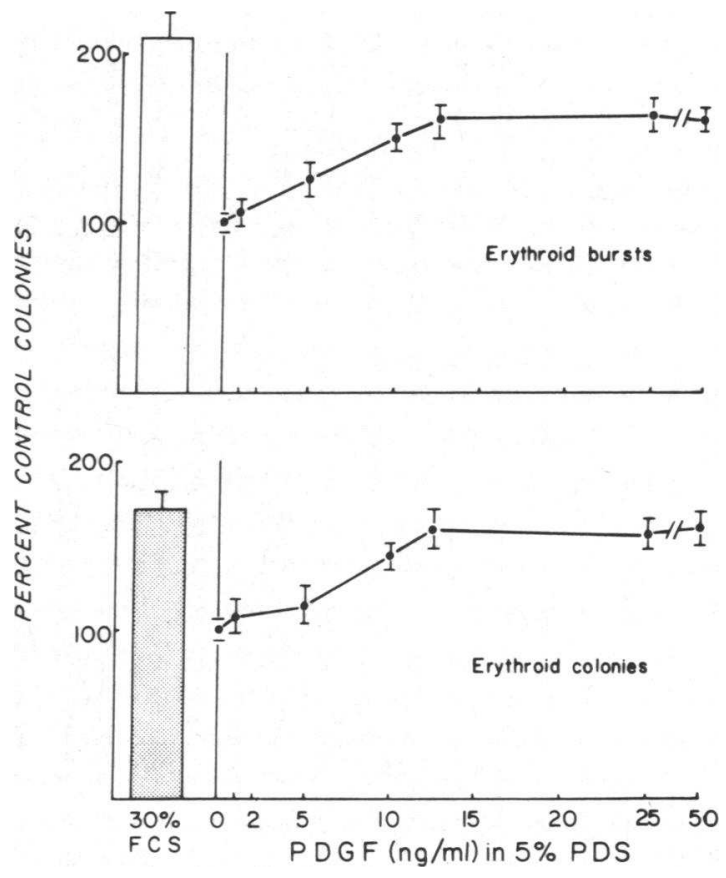

Figure 3. The effect of pure PDGF on erythroid colony and burst growth is shown. Erythroid colony and burst growth were determined for the indicated concentrations of purified PDGF in 5\% PDS and 1.5 U Ep/ml. Error bars indicate the SEM of four separate experiments carried out in triplicate, and the results are normalized to colony numbers in 5\% PDS with no PDGF (100\%). Optimal colony growth in $30 \%$ FCS is shown at the left for comparison. 


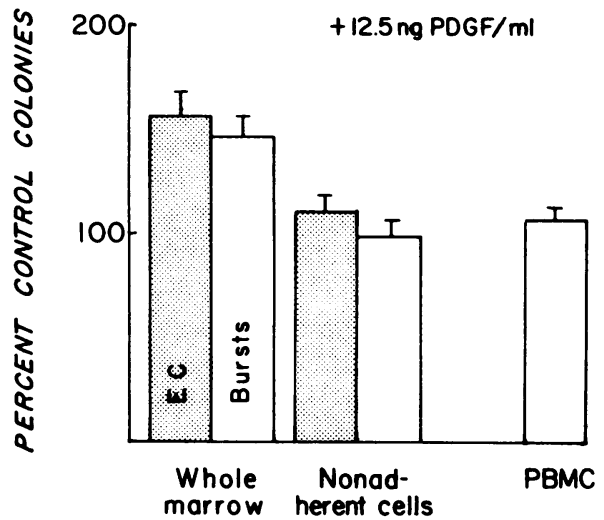

Figure 4. The effect of removal of the adherent marrow cells on PDGF enhancement of erythroid colony and burst growth. $12.5 \mathrm{ng}$ of PDGF were added to cultures of whole marrow, nonadherent marrow cells, and peripheral blood mononuclear cells (PBMC), and erythroid colony (stippled bars) and burst (open bars) growth determined. The results are expressed as the mean $( \pm$ SEM) percentage of erythroid colonies as compared with control cultures in 5\% PDS $(100 \%)$, and are based on three separate studies conducted in triplicate.

normally in the vessel wall and marrow stroma: fibroblasts, smooth muscle cells, or endothelial cells. After 7 and $13 \mathrm{~d}$ of culture, PDGF had stimulated the growth of fibroblasts and smooth muscle cells in the underlayer to visual subconfluence. No effect was observed on endothelial cell growth. Simultaneously, as shown in Fig. 5, the numbers of erythroid colonies and bursts growing in the overlayer were increased significantly in the plates containing PDGF and fibroblasts $(+85$ and $+72 \%$ for CFU-E and BFU-E, respectively) or smooth muscle cells ( +75 and $+58 \%$ for CFU-E and BFU-E, respectively). No enhancement of erythroid progenitor cell growth was observed in the cultures with PDGF and endothelial cells.

The same culture system was used to study the effect of PDGF on peripheral blood BFU-E growth. Again, peripheral blood BFU-E growth was enhanced by PDGF in the presence

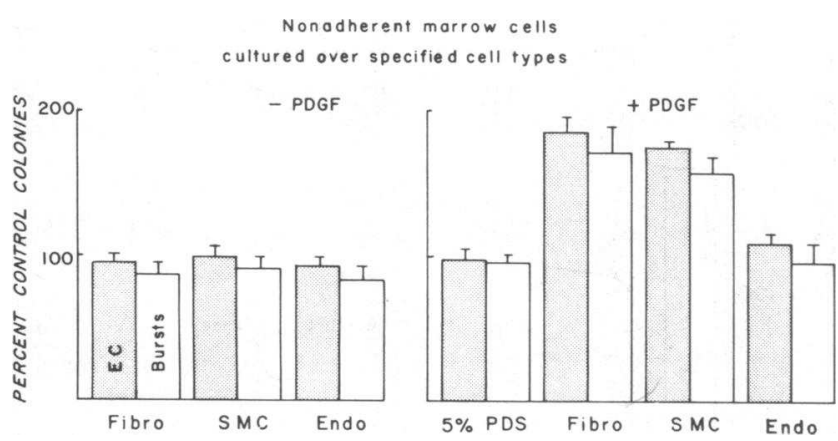

Figure 5. The requirement of specific cell populations for PDGF enhancement of erythroid colony and burst growth. Nonadherent marrow cells were cultured in a two-layer system over $10^{3}$ fibroblasts (Fibro), smooth muscle cells (SMC), or endothelial cells (Endo), in the presence or absence of a final concentration of $12.5 \mathrm{ng}$ PDGF/ $\mathrm{ml}$. This was achieved by adding the PDGF to both layers of the two-layer system. The error bars represent the SEM of three experiments conducted in triplicate, and results are expressed as the mean percentage as compared with control cultures in 5\% PDS (100\%). of fibroblasts or smooth muscle cells, but not with endothelial cells in the underlayer (data not shown).

\section{Discussion}

The in vitro observation that serum contains growth-promoting activity for connective tissue cells not present in plasma (11) led to the discovery that platelets contain mitogens that are released during coagulation which stimulate the growth of 3T3 cells (12), smooth muscle cells (13), and glial cells (14). Recently, Dainiak et al. (1) reported that factors released from thrombin-treated platelets and the purified platelet mitogen, PDGF, enhanced human erythropoiesis in vitro.

In the present study, we confirm that serum prepared from PRS supports marrow erythroid colony growth better than serum prepared from PDS (Fig. 2). This enhancing effect was similar for both primitive (BFU-E) and mature (CFU-E) erythroid progenitors, suggesting that this growth-promoting activity does not depend on the state of maturation of the progenitor. PRS, however, had no effect on the growth of peripheral blood BFU-E compared with PDS. This suggests that either the circulating stem cells are distinct in their responsiveness or that the target cells for PDGF are not present in peripheral blood.

The effect of PRS could be reproduced, at least in part, by purified PDGF in a dose-dependent fashion (Fig. 3). This suggested that PDGF is a major mitogenic factor in the PRS. However, with our experimental conditions, the $50 \%$ stimulatory effect observed with PRS is due to $0.7 \mathrm{ng} P D G F / m l$ as determined by radioreceptor assay, whereas the same concentration had no detectable effect on colony growth in the doseresponse curve described for pure PDGF. In addition, a monospecific anti-human PDGF antibody only partially reversed the enhancing effects of PRS on erythroid progenitor cell growth (Fig. 2). These observations suggest that only part of the enhancement by PRS can be ascribed to PDGF. As demonstrated by Heldin and coworkers $(15,16)$, platelets contain mitogens that are immunochemically and chemically distinct from PDGF, one of which has been determined to be an epidermal growth factorlike molecule (17). Activated platelets also release catecholamines (18) and prostaglandins (19), which stimulate erythroid colony growth $(20,21)$.

We have investigated the mechanisms by which pure PDGF influences in vitro erythropoiesis. All cells which respond to PDGF have been shown to contain specific cell surface receptors $(2,3)$. No PDGF receptors have been found on lymphoid cells, although leukocytes have been shown to be attracted chemotactically by PDGF $(22,23)$. Two cell types known to influence the growth of hematopoietic cells in culture were investigated as possible target cells of PDGF: the mononuclear phagocytes and stromal elements present in the marrow. The role of these cells was investigated by their removal by adherence and examination of cultures containing only nonadherent marrow cells. In the absence of the adherent marrow cells, no enhancement by PDGF was detected (Fig. 4). The requirement for adherent cells to detect PDGF enhancement suggests that the action of PDGF is indirect. Although monocytes and macrophages are known to produce erythroid burstpromoting activity (24), PDGF receptors have not been found on these cells. In addition, although peripheral blood mononuclear cells contain $\sim 30 \%$ monocytes, neither PRS nor pure PDGF enhanced peripheral blood BFU-E growth (Fig. 4). 
PDGF has been shown to specifically stimulate cells of connective tissue origin $(2,3)$, including adherent or stromal cells, in human long-term marrow cultures from both normal and chronic myelogenous leukemia patients (25), and these cells may interact with hematopoietic progenitors in the marrow stroma. Consistent with this, the erythroid-enhancing effect of PDGF was restored when fibroblasts and smooth muscle cells were cultured in a two-layer system with nonadherent marrow cells and peripheral blood cells (Fig. 5). These observations are in accord with a previous report that fibroblasts improved the maintenance of CFU-E in suspension culture (26). Since, in our experiments, marrow and mesenchymal cells were grown in separate layers, stimulation of erythroid colony growth was not related to direct contact between cells, and the PDGF effect is most likely mediated by a diffusable factor.

From these studies we conclude that PDGF acts on erythroid progenitors via the stimulation of mesenchymal cells in marrow stroma and possibly in the vessel wall. Since local platelet activation and release of PDGF would be required in vivo for enhancement by PDGF from platelets, it is unlikely that this system modulates erythropoiesis under normal physiologic conditions. However, it remains to be established whether these in vitro observations might have in vivo relevance in disorders characterized by intravascular coagulation, myelofibrosis, or vasculitis. In addition, since PDGF-like molecules are produced in vitro by transformed cells (27-30), these observations may be pertinent to clonal disorders of the hematopoietic stem cell with abnormal release of cell products. It is also possible that PDGF-like molecules made by endothelial cells $(30,31)$, smooth muscle cells during development $(32)$ or after injury (33), and macrophages (Shimokado, K., E. W. Raines, and R. Ross, submitted for publication), may modulate erythropoiesis within their microenvironments. These observations clearly provide an example of the influence of growth factors in vitro on hematopoietic progenitors via cells of the marrow microenvironment.

\section{Acknowledgments}

The expert technical assistance of Nancy Lin and Karen Tittle, and help with preparation of the manuscript by Ms. Carole Flynn, are gratefully acknowledged.

This work was supported by research grants AM 19410, CA 31516, and HL 18645 from the National Institutes of Health, Department of Health and Human Services, and by a grant from R. J. Reynolds, Inc., Winston-Salem, NC, to Dr. Ross.

\section{References}

1. Dainiak, N., G. Davies, M. Kalmanti, J. Lawler, and V. Kulkorni. 1983. Platelet-derived growth factor promotes proliferation of erythroid progenitor cells in vitro. J. Clin. Invest. 71:1206-1214.

2. Heldin, C. H., B. Westermark, and A. Wasteson. 1981. Specific receptors for platelet-derived growth factor on cells derived from connective tissue and glia. Proc. Natl. Acad. Sci. USA. 78:3664-3668.

3. Bowen-Pope, D. F., and R. Ross. Platelet-derived growth factor II. Specific binding to cultured cells. J. Biol. Chem. 257:5161-5171.

4. Messner, H. A., J. E. Till, and E. A. McCulloch. 1973. Interacting cell populations effecting granulopoietic colony formation by normal and leukemic human marrow cells. Blood. 42:701-710.

5. Ross, R., and B. Kariya. 1980. Handbook of Physiology, Vol. II. American Physiological Society, Wash., DC. 69-91.
6. Wall, R. T., L. A. Harker, L. J. Quadracci and G. E. Striker. 1978. Factors influencing endothelial proliferation in vitro. J. Cell Physiol. 96:203-214.

7. Iscove, N. N., F. Sieber, and K. H. Winterhalter. 1974. Erythroid colony formation in culture of mouse and human bone marrow: analysis of the requirement for erythropoietin by gel filtration and chromatography on agarose-concanavalin A. J. Cell Physiol. 83:309320.

8. Raines, E. W., and R. Ross. 1982. Platelet-derived growth factor I. High yield purification and evidence for multiple forms. J. Biol. Chem. 257:5154-5160.

9. Lowry, O. H., N. J. Rosenbrough, A. L. Farr, and R. J. Randall. 1951. Protein measurement with the folin phenol reagent. J. Biol. Chem. 193:265-274.

10. Vogel, A., E. W. Raines, B. Kariya, M. J. Rivest, and R. Ross. 1978. Coordinate control of $3 T 3$ cell proliferation by platelet-derived growth factor and plasma components. Proc. Natl. Acad. Sci. USA. 75:2810-2814.

11. Balk, S. D., J. F. Whitfield, T. Youdale, and A. C. Braun. 1973. Roles of calcium, serum, plasma and folic acid in the control of proliferation of normal and Rous Sarcoma Virus infected chicken fibroblasts. Proc. Natl. Acad. Sci. USA. 70:675-679.

12. Kohler, N., and A. Lipton. 1974. Platelets as a source of fibroblast growth promoting activity. Exp. Cell Res. 87:297-301.

13. Ross, R., J. Glomset, B. Kariya, and L. Harker. 1974. A platelet dependent serum factor that stimulates the proliferation of arterial smooth muscle cells in vitro. Proc. Natl. Acad. Sci. USA. 71:12071210.

14. Westermark, C., and A. Wasteson. 1976. A platelet factor that stimulates human normal glial cells. Exp. Cell Res. 98:170-174.

15. Heldin, C. H., A. Wasteson, and B. Westermark. 1977. Partial purification and characterization of platelet factors stimulating the multiplication of normal human glial cells. Exp. Cell Res. 109:429437.

16. Heldin, C. H., B. Westermark, and A. Wasteson. 1981. Demonstration of an antibody against platelet-derived growth factor. Exp. Cell Res. 136:255-261.

17. Oka, Y., and D. N. Orth. 1983. Human plasma epidermal growth factor/beta-urogastrone is associated with blood platelets. J. Clin. Invest. 72:249-259.

18. Mustard, J. F., and M. A. Packham. 1970. Factors influencing platelet function-adhesion, release and aggregation. Pharmacol. Rev. 22:97-187.

19. Smith, J. B., C. Ingerman, and J. J. Kocsis. 1973. Formation of prostaglandins during the aggregation of human platelets. J. Clin. Invest. 52:965-969.

20. Rossi, G. B., A. R. Migliaccio, F. Lettieri, M. Di Rosa, G. Mastroberardino, and C. Peschle. 1980. In vitro interactions of PGE and cAMP with murine and human erythroid precursors. Blood. 56: 74-79.

21. Brown, J., and J. W. Adamson. 1977. Modulation of in vitro erythropoiesis: the influence of beta-adrenergic agonists on erythroid colony formation. J. Clin. Invest. 60:70-77.

22. Williams, L. T., H. N. Atoniades, and E. F. Goetzl. 1983 Platelet-derived growth factor stimulates more 3T3 cell mitogenesis and leukocyte chemotaxis through different structural determinants. $J$. Clin. Invest. 72:1759-1763.

23. Deuel, T. F., R. M. Senior, J. S. Huang, and G. L. Griffin. 1982. Chemotaxis of monocytes and neutrophils to platelet-derived growth factor. J. Clin. Invest. 69:1046-1049.

24. Zuckerman, K. S. 1981. Human erythroid burst-forming units growth in vitro is dependent on monocytes, but not $\mathrm{T}$ lymphocytes. J. Clin. Invest. 67:702-709.

25. Rosenfeld, M., A. Keating, D. F. Bowen-Pope, J. W. Singer, and $R$. Ross. Responsiveness of the in vitro hematopoietic microenvironment to platelet-derived growth factor. J. Leuk. Res. In press.

26. Ghio, R., G. Bianchi, B. Lowenberg, K. A. Dicke, and F. 
Ajmar. 1977. Effects of fibroblasts on the growth of erythroid progenitor cells in vitro. Exp. Hematol. 5:341-347.

27. Heldin, C.-H., B. Westermark, and A. Wasteson. 1980. Chemical and biological properties of a growth factor from human-cultured osteosarcoma cells: resemblance with platelet-derived growth factor. $J$. Cell Physiol. 105:234-246.

28. Deuel, T. F., J. S. Huang, S. S. Huang, P. Stroobant, and M. D. Waterfield. 1983. Expression of a platelet-derived growth factorlike protein in simian sarcoma virus transformed cells. Science (Wash. DC). 221:1348-1350.

29. Owen, A. J., P. Pantazis, and H. N. Antoniades. 1984. Simian sarcoma virus-transformed cells secrete a mitogen identical to plateletderived growth factor. Science (Wash. DC). 225:54-56.

30. Bowen-Pope, D., A. Vogel, and R. Ross. 1984. Production of platelet-derived growth factor-like molecules and reduced expression of platelet-derived growth factor receptors accompanies transformation by a wide spectrum of agents. Proc. Natl. Acad. Sci. USA. 81:23962400.

31. DiCorleto, P. E., and D. F. Bowen-Pope. 1983. Cultured endothelial cells produce a platelet-derived growth factor-like protein. Proc. Natl. Acad. Sci. USA. 80:1919-1923.

32. Siefert, R. S., S. M. Schwarz, and D. F. Bowen-Pope. 1984. Developmentally regulated production of platelet-derived growth factorlike molecules. Nature (Lond.). 311:669-671.

33. Walker, L. N., D. F. Bowen-Pope, and M. A. Reidy. 1984. Secretion of platelet-derived growth factor (PDGF)-like activity by arterial smooth muscle cells is induced as a response to injury. $J$. Cell. Biol. 99:416a. (Abstr.) 